\title{
Az Egészségbiztosítási Alap munkaerőpiaci kapcsolódásai Magyarországon
}

\author{
Boncz Imre dr. ${ }^{1}$ - Kovács Gábor dr. ${ }^{2}$ \\ ${ }^{1}$ Pécsi Tudományegyetem, Egészségtudományi Kar, Egészségbiztosítási Intézet, Pécs \\ ${ }^{2}$ Széchenyi István Egyetem, Egészség- és Sporttudományi Kar, Győr
}

\begin{abstract}
Rövidítések
CSED = csecsemőgondozási díj; E. Alap = Egészségbiztosítási Alap; GDP = (gross domestic product) bruttó hazai termék; GYED = gyermekgondozási díj; GYES = gyermekgondozási segély; KSH = Központi Statisztikai Hivatal; NRSZH = Nemzeti Rehabilitációs és Szociális Hivatal; TGYS = terhességigyermekágyi segély
\end{abstract}

A magyar lakosság egészségi állapota meghatározó szerepet tölt be a lakosság életminőségében. Magyarországon 1990 és 2010 között a születéskor várható átlagos élettartam emelkedett, ugyanakkor a lakosság egészségi állapotát tükröző életminőség érdemben nem változott $[1,2]$. Az egészségügyi ellátórendszer finanszírozásának, forrásallokációjának egyik fontos kérdése a hatékonyság, a társadalmi egészségnyereség optimalizálása a rendelkezésre álló források optimális felhasználásával [3].

Magyarországon a közfinanszírozott egészségügyi ellátások meghatározó részét az állam az Egészségbiztosítási Alap (E. Alap) révén finanszírozza. Az Egészségbiztosítási Alap az egészségügyi ellátáshoz kapcsolódó természetbeni és pénzbeli ellátások finanszírozására egyaránt fedezetül szolgál. Az utóbbi években több orvosi és gazdasági témájú közlemény is vizsgálta az E. Alap finanszírozási kérdéseit [4-7].

A Pécsi Tudományegyetem Egészségtudományi Kara és a Széchenyi István Egyetem Egészség- és Sporttudományi Kara közös, „Az Egészségbiztosítási Alap munkaerôpiaci kapcsolódásai” címú kutatási programjának keretében az E. Alapnak a munkaerőpiaci reintegrációhoz kapcsolódó elemeit vizsgáltuk, különös tekintettel a rehabilitációs ellátásokhoz, a táppénzes kifizetésekhez és a gyermekvállaláshoz kapcsolódó elemekre.

Boncz és mtsai a közfinanszírozott kardiológiai rehabilitációs fekvőbeteg-ellátás, illetve a neuromusculoskeletalis rehabilitáció teljesítménymutatóinak feltérképezését végezték el Magyarországon. Eredményeik szerint a kardiológiai és a neuromusculoskeletalis rehabilitáció eseté- ben egyaránt mind a rehabilitációságyszám-kapacitásokban, mind az ezen egészségügyi szolgáltatásokhoz való hozzáférésben jelentős területi egyenlőtlenségek találhatók. Az akut szívinfarktuson átesett betegek esetében igen alacsony $(6,6-7,6 \%)$ részvételi arányt találtak a kardiológiai rehabilitációs ellátások terén $[8,9]$.

Varga és mtsai a hazai gyógyfürdőintézményekhez kötődő, az egészségbiztosító által közfinanszírozott egészségügyi ellátások igénybevételi és egészségbiztosítási mutatóinak elemzését végezték el. A gyógyfürdőkben megvalósult ellátások társadalombiztosítási támogatására a vizsgált években közel 4 milliárd forintot fordított a Nemzeti Egészségbiztosítási Alapkezelő. A gyógyfürdőkben társadalombiztosítási finanszírozással megvalósuló ellátások igénybevételében az évek alatt jelentős változás országosan nem következett be, azonban nemek, korcsoportok és megyék szerinti bontásban érdemi területi eltérések mutatkoznak [10].

Kovács a megváltozott munkaképességű személyek részére kifizetett és jelenleg az E. Alap költségvetésének közel 30\%-át kitevő pénzbeli ellátásokat terhelő részét, és annak változásait elemezte. Kimutatta, hogy a Nemzeti Rehabilitációs és Szociális Hivatal (NRSZH) adatsora szerint a 2011. évben 845913 fó részesült rokkantsági, baleseti rokkantsági nyugdíjban, átmeneti járadékban, rendszeres szociális segélyben, míg az új orvosszakmai, illetve komplex értékelési szempontrendszer bevezetését követően a 2015. évben 385819 fö, ez pedig jelentős összlétszámcsökkenést igazol. A Központi Statisztikai Hivatal $(\mathrm{KSH})$ adatai ugyanakkor azt mutatják, hogy az új rokkantsági ellátások száma 2012 és 2016 között ennek ellenére fokozatosan növekedett (2012: 44486 fó, 2013: 64512 fó, 2014: 53128 fó, 2015: 82424 fó, 2016: 94997 fó) [11].

Nogel az E. Alap pénzbeli ellátásaiból a táppénz igénybevételére és a táppénzkifizetésekre vonatkozó adatokat dolgozta fel az 1997 és 2017 közötti időszakra. Az E. Alap táppénzre fordított éves kiadása a 2005-2008-as időszakban 90-98 milliárd forint között mozgott, majd 


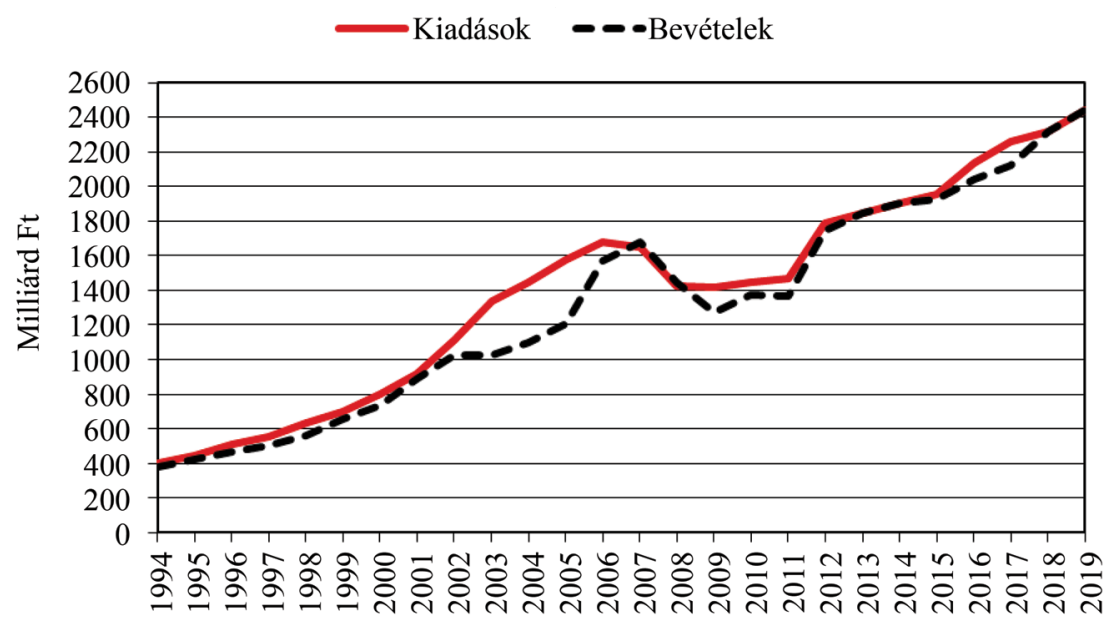

1. ábra

$\mid \begin{aligned} & \text { Az Egészségbiztosítási Alap bevételeinek és kiadásainak alakulása } 1994 \text { és } 2019 \text { között } \\ & \text { Forrás: Nemzeti Egészségbiztositási Alapkezelő }\end{aligned}$

2009-ben érte el legmagasabb értékét (101,57 milliárd Ft). Ezt követően csökkent a táppénzkiadás, majd 2014től növekedésnek indult, míg 2017-re ismét megközelítette a 100 milliárd forintot [12].

Szombati a tanulmányában a rendszerváltástól napjainkig eltelt időszak adatait vizsgálva a szociális ellátások közül a gyermekvállalással kapcsolatosan kifizetett és jelenleg az E. Alap költségvetésének pénzbeli ellátásokat terhelő részét, annak változásait elemezte. Áttekintő közleményében bemutatta a gyermekgondozást segítő ellátást (GYES), a gyermekgondozási díjat (GYED), a csecsemőgondozási díjat (CSED, 2015-ig: terhességigyermekágyi segélyt, TGYS) érintő szabályozási környezetet és ezek változását [13].

Balassa és mtsai közleményükben feltárták Magyarország 2010 és 2016 közötti egészségbiztosítási kiadásainak, valamint a gyógyszerekre adott társadalombiztosítási támogatásoknak a mértékét. Fontos megállapításuk, hogy Magyarországon az E. Alap kiadásai a bruttó hazai termék (GDP) arányában a 2010. évi 5,5\%-ról 2016-ban 6,1\%-ra emelkedtek [14].

$\mathrm{Az}$ E. Alap természetbeni és pénzbeli ellátásainak szabályozása igyekezett követni a munkaerőpiaci, demográfiai kihívásokat. Amint az 1. ábra is szemlélteti, a 2003 és 2005 közötti jelentős hiány a későbbiekben már nem ismétlődött meg, az E. Alap gazdálkodása tehát bizonyos értelemben konszolidálódott [15]. A jövőben fontos kihívás lesz az egészségbiztosítási rendszer fenntartható fejlődése és ennek hozzájárulása a lakosság egészségi állapotának további javításához, munkaerôpiaci helyzetének erősítéséhez, végső soron pedig a nemzetgazdaság fejlődésének előmozdításához.

Anyagi támogatás: A közlemény a Magyar Nemzeti Bank Pallas Athéné Innovációs és Geopolitikai Alapítványának (PAIGEO) támogatásával készült, „A pénzbeli és természetbeni ellátások arányai az Egészségbiztositási Alap költségvetésében a munkaerōpiaci folyamatok tükrében” címú projekt keretében.

\section{Köszönetnyilvánítás}

A Munkacsoport tagjai köszönetet mondanak a Magyar Nemzeti Bank Pallas Athéné Innovációs és Geopolitikai Alapítványának (PAIGEO) a kutatómunkához nyújtott támogatásért. Külön köszönjük továbbá Prof. Dr. Papp Zoltán főszerkesztő úrnak és az Akadémai Kiadónak az Orvosi Hetilap jelen különszámának megjelentetéséhez biztosított támogatást.

\section{Irodalom}

[1] Boncz I, Vajda R, Ágoston I, et al. Changes in the health status of the population of Central and Eastern European countries between 1990 and 2010. Eur J Health Econ. 2014; 15(Suppl 1): S137-S141.

[2] Baji P, Brodszky V, Rencz F, et al. Health status of the Hungarian population between 2000-2010. [A magyar lakosság egészségi állapota 2000 és 2010 között.] Orv Hetil. 2015; 156: 2035-2044. [Hungarian]

[3] Fadgyas-Freyler P. Hungarian health resource allocation from the viewpoint of the English methodology. [A magyar egészségügyi forráselosztás vizsgálata az angliai módszerrel.] Orv Hetil. 2018; 159: 183-191. [Hungarian]

[4] Gresz M. Evaluating the National Health Insurance database of Hungary from the aspect of a health insurance specialist. $[\mathrm{Az}$ Országos Egészségbiztosítási Pénztár adatbázisa az egészségbiztosítási szakorvos szemével.] Orv Hetil. 2012; 153: 12341239. [Hungarian]

[5] Endrei D, Molics B, Ágoston I. Multicriteria decision analysis in the reimbursement of new medical technologies: real-world experiences from Hungary. Value Health 2014; 17: 487-489.

[6] Boncz I, Evetovits T, Dózsa Cs, et al. The Hungarian Care Managing Organization Pilot Program. Value Health Reg Issues $2015 ; 7: 27-33$.

[7] Endrei D, Zemplényi A, Molics B, et al. The effect of performance-volume limit on the DRG based acute care hospital financing in Hungary. Health Policy 2014; 115: 152-156. 
[8] Boncz I, Sebestyén A, Csákvári T, et al. Performance indicators of cardiac rehabilitation in Hungary. [A kardiológiai rehabilitáció teljesítménymutatói Magyarországon.] Orv Hetil. 2019; 160(Suppl 1): 6-12. [Hungarian]

[9] Boncz I, Endrei D, Csákvári T, et al. Health policy indicators of neuromusculosceletal rehabilitation in Hungary. [A neuromusculoskeletalis rehabilitáció szakmapolitikai indikátorai Magyarországon.] Orv Hetil. 2019; 160(Suppl 1): 13-21. [Hungarian]

[10] Varga V, Boncz I, Sebestyén A, et al. Utilization indicators of balneotherapy in Hungary. [A gyógyfürdőellátások igénybevételi mutatói Magyarországon.] Orv Hetil. 2019; 160(Suppl 1): 2228. [Hungarian]

[11] Kovács G. Changes in disability, reduced working ability and rehabilitation benefits in Hungary between 1990 and 2015. [A rokkantság, megváltozott munkaképesség, rehabilitációs ellátások változása Magyarországon 1990 és 2015 között.] Orv Hetil. 2019; 160(Suppl 1): 29-36. [Hungarian]

[12] Nogel M. Sick-pay trends of the National Health Insurance Fund of Hungary between 1997 and 2017. [Az Egészségbiztosítási
Alap táppénzes trendjei Magyarországon 1997 és 2017 között.] Orv Hetil. 2019; 160(Suppl 1): 37-42. [Hungarian]

[13] Szombati I. Social services in the social security system of family support. [Szociális ellátások a társadalombiztosítási családtámogatás rendszerében.] Orv Hetil. 2019; 160(Suppl 1): 43-48. [Hungarian]

[14] Eisingerné Balassa B, Csákvári T, Ágoston I. Health insurance pharmaceutical expenditures in Hungary. [Az egészségbiztosítási gyógyszerkiadások alakulása Magyarországon.] Orv Hetil. 2019; 160(Suppl. 1): 49-54. [Hungarian]

[15] Boncz I, Sebestyén A. Financial deficits in the health services of the UK and Hungary. Lancet 2006; 368: 917-918.

(Boncz Imre dr., Pécs, Mária u. 5-7., 7621 e-mail: imre.boncz@etk.pte.hu) 